\title{
Perspektywy wykorzystania inżynierii genetycznej do zwiększenia wydajności fotosyntezy
}

\section{STRESZCZENIE}

W drugiej połowie XX wieku miał miejsce znaczący wzrost produkcji rolnej, jednak uważa się, iż uzyskiwany obecnie plon jest maksymalnym, jaki można zebrać z odmian otrzymywanych tradycyjnymi metodami. Ponieważ spodziewany jest dalszy wzrost zapotrzebowania na produkty pochodzenia roślinnego, konieczne jest poszukiwanie innych rozwiązań pozwalających na podniesienie produktywności roślin. Postuluje się wykorzystanie w tym celu metod inżynierii genetycznej. W niniejszym artykule omówione zostały kierunki badań nad zwiększeniem wydajności obu faz fotosyntezy, w szczególności koncepcje dotyczące badań nad usprawnieniem Rubisco, wprowadzeniem do roślin uprawnych mechanizmów zagęszczania $\mathrm{CO}_{2}$, ograniczeniem strat wynikających z fotooddychania oraz usprawnieniem etapu regeneracji fazy ciemnej.

\section{WPROWADZENIE}

$\mathrm{W}$ drugiej połowie $\mathrm{XX}$ wieku miał miejsce znaczący wzrost produktywności roślin uprawnych. Wynikał on z wprowadzenia nowych wysokoplennych odmian, stosowania nawozów sztucznych oraz środków ochrony roślin [1]. Szacuje się, że w 1951 roku średni plon zbóż wynosił 1,2 tony/ha, podczas gdy w 1993roku otrzymywano niemal dwa razy tyle, 2,3 tony/ha [2]. W porównaniu z wiekiem ubiegłym, w XXI stuleciu wzrost produktywności najważniejszych gatunków roślin uprawnych był jednak niewielki. Uważa się, iż uzyskiwany obecnie plon jest maksymalnym, jaki można uzyskać z odmian otrzymywanych tradycyjnymi metodami $[1,3]$. Poza wykorzystaniem roślin w celach konsumpcyjnych, zwiększa się popyt na inne produkty pochodzenia roślinnego np. biopaliwa. Konieczne jest zatem poszukiwanie innych rozwiązań pozwalających na podniesienie produktywności roślin. Postuluje się wykorzystanie w tym celu metod inżynierii genetycznej [3]. Produktywność roślin zależy od wielu czynników, dlatego badania prowadzone są w wielu kierunkach. Podejmowane są próby wpływania na szybkość wzrostu i fazy rozwojowe roślin, czy zwiększania ich odporności na stresy biotyczne i abiotyczne. Wiele badań dotyczy możliwości zwiększenia wydajności fotosyntezy, czyli procesu odpowiedzialnego za asymilację $\mathrm{CO}_{2}$ i produkcję biomasy.

Fotosynteza jest procesem bardzo złożonym. Możemy w niej jednak wyróżnić dwa podstawowe etapy: tak zwaną fazę jasną fotosyntezy oraz fazę ciemną. Reakcje fazy jasnej zachodzą w błonach tylakoidów i prowadzą do uzyskania siły redukcyjnej, czyli NADPH oraz ATP, które następnie są wykorzystywane do asymilacji $\mathrm{CO}_{2}$, zachodzącej w fazie ciemnej. W ciągu ostatnich dwóch dziesięcioleci proponowano i sprawdzano skuteczność rozwiązań mających na celu zwiększenie wydajności rozmaitych etapów zachodzących podczas obydwu tych etapów.

\section{STRATEGIE USPRAWNIANIA FAZY JASNEJ FOTOSYNTEZY}

Faza jasna fotosyntezy jest przykładem procesu, który przez miliardy lat ewolucji został wysoce zoptymalizowany, reakcje zachodzące w błonach tylakoidów są szybkie i bardzo wydajne. Specyficzne barwniki fotosyntetyczne czy białka antenowe pojawiały się u określonych grup systematycznych i były udoskonalane w ich obrębie [4]. Rośliny wyższe "odziedziczyły” aparat fotosyntetyczny po zielenicach, podczas gdy odlegle spokrewnione organizmy fotosyntetyczne dysponują odmiennymi sposobami na wydajną absorpcję światła, czy ochronę przed jego nadmiarem. Inżynieria genetyczna umożliwia zaimplementowanie pożądanych genów organizmom niespokrewnionym z "dawcą", tym samym pozwala ominąć ograniczenia wynikające z przeszłości ewolucyjnej [3].

Część badań nad usprawnieniem fazy jasnej fotosyntezy dotyczy zwiększenia wydajności absorpcji światła. Kluczowym elementem aparatu fotosynte-

\section{Beatrycze Nowicka}

Jerzy Kruk

Zakład Fizjologii i Biochemii Roślin, Wydział Biochemii, Biofizyki i Biotechnologii, Uniwersytet Jagielloński, Kraków

Zakład Fizjologii i Biochemii Roślin, Wydział Biochemii, Biofizyki i Biotechnologii, Uniwersytet Jagielloński, ul. Gronostajowa 7, 30-387 Kraków; tel.: (12) 66463 61, e-mail: jerzy.kruk@uj.edu.pl

Artykuł otrzymano 22 stycznia 2018 r. Artykuł zaakceptowano 15 lutego 2018 r.

Słowa kluczowe: asymilacja węgla, fotooddychanie, inżynieria genetyczna, mechanizmy zagęszczania $\mathrm{CO}_{2}$, rośliny $\mathrm{C}_{4}$, Rubisco

Wykaz skrótów: Bchl - bakteriochlorofil; CCM - mechanizmy zagęszczania $\mathrm{CO}_{2}$; Chl - chlorofil; Rubisco - karboksylaza/oksygenaza rybulozo-1,5-bisfosforanu; PEP - fosfoenolopirogronian; RuBP - rybulozo-1,5-bisfosforan

Podziękowania: Praca powstała w ramach realizacji projektu badawczego 2015/19/B/ NZ9/00422, finansowanego przez Narodowe Centrum Nauki. 
tycznego, determinującym jego zdolność do pochłaniania energii promieniowania elektromagnetycznego są barwniki fotosyntetyczne. W toku ewolucji organizmy fotosyntetyczne specjalizowały się w wykorzystywaniu światła o takim składzie spektralnym, jaki był dostępny w niszy ekologicznej, w której występowały. Doprowadziło to do sytuacji, w której zakres widma promieniowania elektromagnetycznego wykorzystywanego przez rośliny wyższe do fotosyntezy jest stosunkowo wąski. Ponieważ rośliny uprawne nie muszą konkurować o dostęp do światła, cechą pożądaną z punktu widzenia człowieka byłaby możliwość korzystania z jak najszerszego zakresu widma światła [4].

U organizmów przeprowadzających fotosyntezę oksygeniczną, czyli sinic i eukariontów fotosyntetycznych, występują dwa fotosystemy absorbujące światło o zbliżonej długości fali, co oznacza, że konkurują one ze sobą o fotony [3]. Jedną z bardziej ambitnych koncepcji inżynierii fotosyntezy jest wprowadzenie do roślin genów kodujących enzymy szlaku biosyntezy bakteriochlorofilu (Bchl) wraz z genami kodującymi centrum reakcji bakterii purpurowych. Pozwoliłoby to na otrzymanie organizmu, który miałby fotosystem zawierający chlorofil (Chl) i absorbujący światło widzialne, a także fotosystem zawierający Bchl i wykorzystujący daleką czerwień oraz bliską podczerwień [3]. Takie rozwiązanie jest jednak wyjątkowo trudne do osiągnięcia, ponieważ wymaga zastąpienia całego fotosystemu i jego systemu anten. Co więcej, szlaki biosyntezy Bchl i Chl współdzielą pierwsze etapy, co oznacza, że konkurowałyby ze sobą o substraty. Hitchcock i współaut. [4] wprowadzili do mutanta bakterii purpurowej Rhodobacter spheroides, niezdolnego do syntezy $\mathrm{Bchl} a$, geny potrzebne do biosyntezy $\mathrm{Chl} a$. Transgeniczna bakteria istotnie produkowała $\mathrm{Chl} a$, jednak ponieważ nie wytwarzała Bchl a potrzebnego jej do fotosyntezy, nie była zdolna do autotroficznego wzrostu [4].

Ponieważ w warunkach naturalnych organizmy fotosyntetyczne konkurują ze sobą, korzystną strategią jest maksymalizacja absorpcji światła i zacienianie sąsiadów. W wyniku tego w słoneczny dzień, górne liście roślin wyższych absorbują więcej światła, niż są w stanie wykorzystać do fotosyntezy. Nadmiar pochłoniętej energii musi być rozpraszany w celu uniknięcia szkodliwych reakcji ubocznych. W tym samym czasie do liści dolnych dociera światło o natężeniu niewystarczającym do wysycenia zachodzącej tam fotosyntezy. Stąd pomysł, by zmodyfikować zawartość barwników w liściach tak, aby górne zawierały ich mniej niż dolne [3]. Brano też pod uwagę modyfikacje powierzchni i orientacji liści [5]. Na określenie optymalizacji wykorzystania światła $\mathrm{w}$ obrębie rośliny używa się w anglojęzycznej literaturze terminu "smart canopy concept" [3].

Sytuacja zbliżona do wyżej opisanej dla roślin lądowych, zachodzi także w przypadku hodowli glonów. Glony znajdujące się $w$ powierzchniowej warstwie wody pochłaniają światło w nadmiarze, natomiast w głębszych warstwach występuje jego niedobór. Przeprowadzono szereg eksperymentów na sinicach i glonach jednokomórkowych ze zmniejszoną zawartością kompleksów antenowych lub zmniejszonymi rozmiarami anten [6-8]. U mutanta Synechocystis PCC 6803 nie syntetyzującego fikocyjaniny, zaobserwowano wyższą produkcję biomasy $\mathrm{w}$ porównaniu $\mathrm{z}$ typem dzikim, gdy hodowano sinice w silnym świetle [7]. Analogiczne wyniki uzyskano dla jednokomórkowej zielenicy Chlamydomonas reinhardtii, u której częściowo wyciszono ekspresję genów z rodziny LHC [8] lub hamowano syntezę LHC na etapie translacji [6].

Postulowano także, że dla zwiększenia produktywności roślin korzystne byłoby skrócenie czasu relaksacji procesów fotoprotekcyjnych odpowiedzialnych za rozpraszanie nadmiaru zaabsorbowanej energii [2].

\section{STRATEGIE USPRAWNIANIA FAZY CIEMNEJ FOTOSYNTEZY}

Jednym z najważniejszych czynników determinujących produktywność roślin jest wydajność asymilacji $\mathrm{CO}_{2}$. Z uwagi na pochodzenie plastydów od sinic, wszystkie fotosyntetyczne eukarionty wiążą $\mathrm{CO}_{2}$ w cyklu Calvina [9]. Kluczowy enzym tego cyklu, karboksylaza/oksygenaza rybulozo-1,5-bisfosforanu (Rubisco) jest jednak daleka od doskonałości.

Rubisco nie dyskryminuje $\mathrm{CO}_{2} \mathrm{iO}_{2}$, co oznacza, że oprócz pożądanej reakcji karboksylacji rybulozo-1,5-bisfosforanu (RuBP), katalizuje także uboczną reakcję utleniania tego substratu, co prowadzi do uwalniania węgla, zamiast do jego wiązania [10]. Cykl Calvina wyewoluował w środowisku niskiej zawartości tlenu w atmosferze lub w warunkach beztlenowych. Nie było zatem presji selekcyjnej na wykształcenie większej selektywności enzymu wiążącego $\mathrm{CO}_{2}$ [11]. Potem jednak stężenie tlenu w atmosferze gwałtownie wzrosło. Obecnie, gdy wynosi ono $21 \%$, podczas gdy stężenie $\mathrm{CO}_{2}$ to $0,04 \%$, u roślin $\mathrm{C}_{3}$, do których należy zdecydowana większość gatunków roślin uprawnych, jedna na 3-4 cząsteczki RuBP jest utleniana przez Rubisco, zamiast ulegać karboksylacji [10]. W wyniku utleniania RuBP powstaje jedna cząsteczka aldehydu 3-fosfoglicerynowego oraz jedna cząsteczka 2-fosfoglikolanu. Fosfoglikolan jest inhibitorem enzymów uczestniczących w metabolizmie węgla i dlatego nie może gromadzić się $\mathrm{w}$ komórkach. Procesem pozwalającym przekształcić fosfoglikolan w związki, które mogą zostać ponownie włączone do metabolizmu podstawowego jest fotooddychanie. Jego przeprowadzanie wymaga dodatkowego nakładu energii, prowadzi też do utraty organicznego węgla i azotu. Przetworzeniu dwóch cząsteczek fosfoglikolanu towarzyszy powstanie jednej cząsteczki $\mathrm{CO}_{2} \mathrm{i}$ jednej cząsteczki $\mathrm{NH}_{3}[12,13]$. Szacuje się, że w temperaturze $25^{\circ} \mathrm{C}$ około $25 \%$ asymilowanego węgla jest tracone podczas fotooddychania, co oznacza, że w skali globalnej rocznie do atmosfery powraca około 29 gigaton organicznego węgla $[1,10]$.

Kolejnym ograniczeniem Rubisco jest niska liczba obrotów enzymu. Dla Rubisco z większości organizmów wynosi ona 1-10 s-1 , podczas gdy dla pozostałych enzymów metabolizmu podstawowego parametr ten zazwyczaj mieści się $\mathrm{W}$ granicach 50-100 s s. $^{-1}$ Aby zapewnić odpowiednią wydajność wiązania węgla, rośliny wytwarzają duże ilości Rubisco. Enzym ten może stanowić nawet do 50\% białek rozpuszczalnych [14]. Obliczono, że około 25\% obecnego w liściach azotu jest przeznaczane na syntezę Rubisco [15]. Innym przystosowaniem służącym usprawnieniu wiązania węgla 
i ograniczeniu fotooddychania są różnorodne mechanizmy zagęszczania $\mathrm{CO}_{2}$ (CCM, ang. Carbon Concentrating Mechanisms) [13].

Można wyróżnić trzy główne kierunki badań zmierzających do zwiększenia wydajności fazy ciemnej fotosyntezy: badania dotyczące usprawnienia Rubisco, inżynierię fotooddychania oraz próby wprowadzenia CCM do najważniejszych gatunków roślin uprawnych.

\section{MODYFIKACJE RUBISCO}

Dla wielu szlaków/cykli metabolicznych podstawowym sposobem na zwiększenie ich wydajności u roślin jest nadekspresja genów kodujących enzym lub enzymy przeprowadzające kluczowe etapy danego procesu. Strategia ta nie sprawdziła się jednak jako sposób podniesienia efektywności fazy ciemnej fotosyntezy, bowiem transgeniczny ryż $\mathrm{z}$ nadekspresją Rubisco nie wykazywał zwiększonej asymilacji $\mathrm{CO}_{2}$ [16]. Podjęto także próby uzyskania Rubisco o ulepszonych parametrach katalitycznych tak, aby mniejsza ilość enzymu była wymagana do wydajnego wiązania węgla. Oznaczałoby to niższe nakłady energii i metabolitów do syntezy Rubisco [17].

Rubisco występujące w naturze różnią się specyficznością i szybkością katalizowanej reakcji. Jednak dla tego enzymu zachodzi ujemna korelacja pomiędzy $k_{\text {cat }}$ i specyficznością enzymu $[15,18]$. W celu podniesienia wydajności karboksylacji, rozważa się wprowadzenie mało selektywnego Rubisco o relatywnie wysokiej k $\mathrm{k}_{\text {cat }}$ razem z CCM, zapewniającym korzystny stosunek $\mathrm{CO}_{2} / \mathrm{O}_{2} \mathrm{w}$ bezpośrednim otoczeniu enzymu (zob. następny podrozdział). Badania wykazały także, że Rubisco pochodzące z krasnostów cechują się korzystnymi parametrami, są one około dwukrotnie bardziej selektywne od enzymów z typowych roślin $\mathrm{C}_{3}$ przy zachowaniu podobnych wartości $\mathrm{K}_{\mathrm{m}}$ oraz maksymalnej szybkości asymilacji $\mathrm{CO}_{2}$. Próbowano ekspresjonować je w roślinach, jednak nie dochodziło tam do poprawnego fałdowania i składania enzymu [15,19]. Pewne nadzieje wiąże się z Rubisco pochodzącymi z okrzemek [20].

Poza badaniami nad naturalnymi formami Rubisco, podejmuje się również próby otrzymania enzymów o ulepszonych własnościach katalitycznych. Opracowano systemy do sztucznej ukierunkowanej ewolucji Rubisco, pozwalające na selekcję enzymu o korzystniejszych właściwościach katalitycznych po przeprowadzeniu losowej mutagenezy. Systemy takie oparto na transgenicznej E. coli, bakterii purpurowej Rhodobacter capsulatus, sinicy Synechococcus PCC 6308 oraz zielenicy Chlamydomonas reinhardtii. Do tej pory nie udało się jednak dzięki tej metodzie uzyskać Rubisco o parametrach katalitycznych korzystniejszych niż te, jakie można spotkać u enzymów występujących w naturze $[17,21,22]$.

Prowadzono także eksperymenty z wykorzystaniem mutagenezy punktowej. Metoda ta okazała się bardzo przydatna w badaniu własności enzymu i jego mechanizmu katalitycznego. Dzięki niej odkryto, które reszty aminokwasowe są ważne dla zapewniania selektywności, a które wpływają na szybkość reakcji [17]. Również i w tym przypadku nie udało się jednak uzyskać znaczącej poprawy parametrów enzymu [3].

Kolejny problem związany z modyfikacjami Rubisco wiąże się z trudnościami, na jakie napotyka się podczas prób jego heterologicznej ekspresji w organizmach transgenicznych. Rubisco roślin wyższych należy do tzw. typu I B i jest heksadekamerem składającym się z 8 dużych podjednostek, pełniących funkcję katalityczną i 8 małych, uczestniczących w regulacji [23]. Duże podjednostki są kodowane w genomie chloroplastowym, natomiast małe w jądrowym. Genomy roślin wyższych zwykle zawierają kilka genów małych podjednostek Rubisco. Pozwala to na zróżnicowaną ekspresję tych genów w zależności od warunków środowiska i etapu rozwoju rośliny [24]. Synteza małych i dużych podjednostek musi być ściśle skoordynowana. Aby powstał aktywny enzym, konieczne są odpowiednie modyfikacje potranslacyjne. Małe podjednostki są transportowane do chloroplastów, gdzie musi dojść do poprawnego fałdowania i składania całego kompleksu z udziałem odpowiednich białek opiekuńczych [15]. Wykazano, że nawet pojedyncze substytucje reszt aminokwasowych mogą mieć znaczny wpływ na poprawne fałdowanie Rubisco $u$ danego gatunku [19]. Aktywność Rubisco zależy też od jej oddziaływania z aktywazą Rubisco [17]. Przeprowadzono szereg eksperymentów, mających na celu otrzymanie roślin transgenicznych z wprowadzonymi genami kodującymi Rubisco, jednak w wielu przypadkach nawet jeśli dochodziło do transkrypcji wprowadzonych transgenów, nie wykrywano produktu białkowego, albo białko było syntetyzowane, ale nie ulegało poprawnemu fałdowaniu i składaniu, lub też aktywność uzyskanego kompleksu była bardzo niska $[17,25]$. Ponieważ zazwyczaj Rubisco składające się z małych i dużych podjednostek pochodzących z różnych gatunków wykazują niższą aktywność od enzymów złożonych z podjednostek pochodzących z tego samego gatunku, należałoby transformować rośliny genami dużych i małych podjednostek jednocześnie. Oznacza to konieczność przeprowadzenia udanej transformacji zarówno genomu jądrowego, jak i chloroplastowego [26].

Innym podejściem jest modifikacja aktywazy Rubisco [24]. Aktywazy Rubisco są enzymami zależnymi od ATP, przeciwdziałającymi hamowaniu Rubisco przez fosforany cukrów. Doświadczenia w warunkach in vitro wykazały, że roślinne aktywazy Rubisco są niestabilne w temperaturze powyżej $30^{\circ} \mathrm{C}$. Zastąpienie natywnej aktywazy Rubisco formami bardziej termostabilnymi pozwoliło uzyskać transgeniczny $A$. thaliana wykazujący większy przyrost biomasy i plon $\mathrm{z}$ nasion $\mathrm{w}$ porównaniu $\mathrm{z}$ typem dzikim, gdy rośliny hodowano w podwyższonej temperaturze [27].

\section{WPROWADZANIE MECHANIZMÓW ZAGĘSZCZANIA DWUTLENKU WĘGLA}

\section{MECHANIZMY ZAGĘSZCZANIA CO $\mathrm{CO}_{2}$ POCHODZĄCE Z SINIC I GLONÓW EUKARIOTYCZNYCH}

Wiele organizmów fotosyntetycznych, zwłaszcza gatunków występujących w środowisku wodnym, wykształciło CCM działające w obrębie pojedynczych komórek. W ich skład wchodzą błonowe transportery $\mathrm{HCO}_{3}^{-}$, anhydrazy

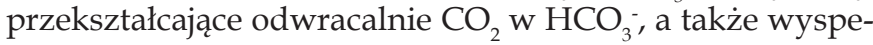


cjalizowane struktury subkomórkowe, gdzie znajduje się Rubisco, a lokalne stężenie $\mathrm{CO}_{2}$ jest znacząco podwyższone. Struktury obecne u sinic (oraz niektórych proteobakterii) nazywamy karboksysomami, natomiast u glonów eukariotycznych występują pirenoidy [28,29].

CCM u sinic cechuje duża wydajność, mogą one zagęszczać $\mathrm{CO}_{2} \mathrm{w}$ bezpośrednim otoczeniu Rubisco nawet tysiąckrotnie. Do tej pory u sinic odkryto pięć systemów pozwalających na pobieranie nieorganicznego węgla. Trzy $\mathrm{z}$ nich oparte są na transporterach $\mathrm{HCO}_{3}{ }^{-}$, dwa kolejne wykorzystują błonowe kompleksy dehydrogenaz NAD(P) $\mathrm{H}$, przekształcające $\mathrm{CO}_{2}$ do $\mathrm{HCO}_{3}^{-}$. Aniony wodorowęglanowe nie mogą swobodnie dyfundować przez błony, dlatego zostają niejako „uwięzione” wewnątrz komórki. Poszczególne gatunki sinic zwykle dysponują kilkoma systemami pobierania nieorganicznego węgla, co pozwala im dostosowywać się do zmiennych warunków środowiska, transportery o wysokim powinowactwie do $\mathrm{HCO}_{3}^{-}$ulegają zwiększonej syntezie $w$ warunkach niedoboru $\mathrm{CO}_{2}[29,30]$. W cytoplazmie komórek sinic znajdują się karboksysomy, wielościenne, uporządkowane makrostruktury zbudowane z Rubisco, anhydrazy węglanowej oraz białek osłonki (ang. shell proteins). W zależności od typu Rubisco obecnego $\mathrm{W}$ karboksysomach (typ I A i I B) wyróżnia się odpowiednio karboksysomy typu $\alpha$ i $\beta$ [31]. Anhydraza węglanowa przekształca $\mathrm{HCO}_{3}^{-}$do $\mathrm{CO}_{2}$, natomiast zadaniem białek osłonki jest ograniczanie dyfuzji $\mathrm{O}_{2}$ do wewnątrz a $\mathrm{CO}_{2}$ na zewnątrz karboksysomów [28].

Eukariotyczne CCM odkryto u wielu glonów, między innymi zielenic, krasnorostów, bruzdnic i okrzemek. Występują one także także u glewików [11,29]. Mechanizmy te są bardzo zróżnicowane i mają pochodzenie polifiletyczne, jednak zasada ich działania jest zbliżona do tej, na jakiej oparte są systemy sinicowe. Różnorodne transportery $\mathrm{HCO}_{3}^{-}$odpowiadają za zagęszczanie anionów węglanowych w stromie chloroplatów. Chloroplastowymi strukturami zawierającymi Rubisco i anhydrazę węglanową są tzw. pirenoidy. Zazwyczaj są one otoczone ziarnami skrobi [29]. Dzięki obecności CCM, okrzemki mogą przeprowadzać wydajną fotosyntezę z udziałem o wiele mniejszych ilości Rubisco w porównaniu z roślinami wyższymi. Enzym ten $\mathrm{u}$ okrzemek stanowi tylko 2-6\% całkowitego białka, a więc kilkanaście razy mniej niż u roślin lądowych [32].

Przeprowadzono eksperymenty, których celem było wprowadzenie CCM do roślin uprawnych [33]. Skupiono się na systemach sinicowych, ponieważ zostały one lepiej poznane [28]. U roślin wyższych występuje Rubisco typu I B, dlatego też badania koncentrują się nad inżynierią $\beta$ -karboksysomów [33]. Uzyskano transgeniczny tytoń, w którym natywne Rubisco zostało zastąpione enzymem $\mathrm{z}$ sinicy Synechococcus elongatus [34,35]. Sinicowe Rubisco posiadają maksymalną szybkość karboksylacji wyższą od enzymów roślinnych, lecz niższe powinowactwo do $\mathrm{CO}_{2}$, są też mniej selektywne [15]. Z tego względu tytoń wytwarzający enzym pochodzący z sinicy, musiał być hodowany w podwyższonym stężeniu $\mathrm{CO}_{2}[34,35]$. Prowadzono także badania nad uzyskaniem transgenicznego tytoniu produkującego karboksysomy. Przejściowa ekspresja genów kodujących białka karboksysomów z Synechococcus elongatus
PCC 7942 z dołączonym peptydem sygnałowym kierującym do chloroplastów doprowadziła do powstawania $\mathrm{w}$ tych organellach uporządkowanych struktur formowanych przez produkty wprowadzonych transgenów [36]. Sukces osiągnięto również $\mathrm{w}$ doświadczeniach mających na celu wprowadzenie do roślin transporterów $\mathrm{HCO}_{3}{ }^{-}$pochodzących z sinic. Uzyskano linie transgeniczne, w których dochodziło do syntezy tych białek, a następnie kierowania ich do osłonek chloroplastów [37-39]. Rozpoczęto także badania nad wprowadzeniem do roślin CCM z zielenic. Do tej pory udało się uzyskać ekspresję wybranych komponentów CCM pochodzących z Chlamydomonas reinhardtii w tytoniu i A. thaliana [40].

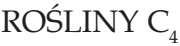

Niektóre rośliny wyższe wykształciły inny mechanizm zagęszczania $\mathrm{CO}_{2}$, nazywany szlakiem $\mathrm{C}_{4}$. Jest on dodatkowym szlakiem wiązania $\mathrm{CO}_{2}$, poprzedzającym, ale nie zastępującym cykl Calvina. $\mathrm{CO}_{2}$ wiązany przez karboksylazę fosfoenolopirogronianu (PEP) jest ponownie uwalniany $\mathrm{w}$ sąsiedztwie Rubisco, która przeprowadza właściwą asymilację węgla. U większości gatunków tego typu, adaptacji metabolicznej towarzyszą przystosowania anatomiczne określane mianem anatomii Kranza. Polegają one na zróżnicowaniu tkanki fotosyntetycznej liścia na mezofil oraz komórki pochwy okołowiązkowej [41]. Miękisz mezofilu zawiera dużo przestworów międzykomórkowych, co ułatwia dyfuzję $\mathrm{CO}_{2}$. W jego komórkach anhydraza węglanowa przekształca $\mathrm{CO}_{2} \mathrm{~W} \mathrm{HCO}_{3}$-, stanowiący substrat dla karboksylazy PEP. W wyniku karboksylacji powstaje czterowęglowy jabłczan (stąd nazwa cyklu). W zależności od podtypu cyklu $C_{4}$ jabłczan może być eksportowany do komórek pochwy okołowiązkowej lub też najpierw następuje transaminacja i transportowanym metabolitem jest asparaginian, który w miejscu docelowym ponownie przekształcany do jabłczanu. W cytozolu komórek pochwy okołowiązkowej dochodzi do dekarboksylacji jabłczanu, uwalniany $\mathrm{CO}_{2}$ po dyfuzji do chloroplastów jest wiązany przez Rubisco, a pirogronian powraca do komórek mezofilu. W pochwie okołowiązkowej nie ma dużych przestworów międzykomórkowych, ponadto skład chemiczny ściany komórkowej jest zmodyfikowany tak, by ograniczać dyfuzję $\mathrm{CO}_{2} \mathrm{z}$ powrotem do mezofilu [41]. Oszacowano, że w chloroplastach roślin $\mathrm{C}_{3}$ stężenie $\mathrm{CO}_{2}$ wynosi poniżej $10 \mu \mathrm{M}$, podczas gdy stężenie tego gazu w chloroplastach pochwy okołowiązkowej roślin $\mathrm{C}_{4}$ osiąga $160 \mu \mathrm{M}$ i więcej [20]. Dzięki temu, podobnie jak to ma miejsce $u$ sinic i zielenic dysponujących CCM, rośliny $\mathrm{C}_{4}$ mogą korzystać z Rubisco o niższej selektywności, a za to wyższej szybkości maksymalnej od enzymów roślin $\mathrm{C}_{3}$ [15]. Dlatego też, rośliny $\mathrm{C}_{4}$ mogą wydajnie asymilować $\mathrm{CO}_{2}$, wytwarzając mniejsze ilości Rubisco, enzym ten stanowi u nich 10-25\% rozpuszczalnych białek liścia, czyli jest go kilkakrotnie mniej niż $\mathrm{u}$ roślin $\mathrm{C}_{3}$ [24].

Cykl $\mathrm{C}_{4}$ wymaga dodatkowego nakładu energii, ale za to umożliwia wydajniejsze wiązanie $\mathrm{CO}_{2}$ oraz ograniczenie utraty wody. Dzięki temu zwiększa dostosowanie roślin $\mathrm{C}_{4^{\prime}}$ zwłaszcza w warunkach sprzyjających fotooddychaniu, takich jak silne światło, wysoka temperatura oraz ograniczona dostępność wody. Szlak $\mathrm{C}_{4}$ wyewoluował niezależnie $\mathrm{u}$ co najmniej 62 grup systematycznych [42]. 
Do roślin $\mathrm{C}_{4}$ należą takie gatunki jak kukurydza i trzcina cukrowa, jednakże większość roślin uprawnych to rośliny $\mathrm{C}_{3}$. Dlatego postulowano, aby za pomocą inżynierii genetycznej wprowadzić cykl $\mathrm{C}_{4}$ do najważniejszych gatunków zbóż $\mathrm{C}_{3}$. Jest to jednak bardzo trudne zadanie. Liczba potrzebnych enzymów i transporterów jest stosunkowo niewielka, jednak do tego aby cykl $\mathrm{C}_{4}$ mógł zachodzić prawidłowo, konieczne jest zapewnienie wymaganej anatomii liści i odpowiedniego składu białkowego chloroplastów [43]. Mimo tego, w ciągu ostatnich 20 lat podejmowano próby wprowadzenia cyklu $\mathrm{C}_{4}$ do roślin $\mathrm{C}_{3}[13]$. Wiele eksperymentów dotyczyło ekspresji genów kodujących enzymy tego cyklu w ryżu [44,45]. Obecnie prowadzi się intensywne badania, mające na celu identyfikację genów odpowiedzialnych za wykształcanie anatomii Kranza i funkcjonalne zróżnicowanie komórek mezofilu oraz pochwy okołowiązkowej [43,46,47]. Ponieważ do wykształcenia cyklu $\mathrm{C}_{4}$ doszło niezależnie wielokrotnie, a podstawowe enzymy cyklu są obecne $\mathrm{w}$ roślinach $\mathrm{C}_{3}$, gdzie pełnią inne funkcje, przypuszcza się, że uzyskanie tego przystosowania metabolicznego jest procesem mniej skomplikowanym, niż można by sądzić na podstawie porównań anatomii i fizjologii roślin $\mathrm{C}_{3} \mathrm{i}_{4}$ [43].

Znane są także gatunki roślin $\mathrm{C}_{4}$, $\mathrm{u}$ których dochodzi do funkcjonalnego różnicowania się chloroplastów w obrębie jednej komórki [48]. Są to jednak albo rośliny wodne, albo sukulenty, co oznacza, że ich fizjologia i anatomia różni się znacznie od tej występującej u najważniejszych gatunków roślin uprawnych [49].

\section{INŻYNIERIA FOTOODDYCHANIA}

Fotooddychanie prowadzi do strat organicznego węgla i azotu. $Z$ tego względu sądzono, że ograniczenie tego procesu powinno wpłynąć korzystnie na produktywność roślin. W praktyce jednak okazuje się, iż fotooddychanie jest ściśle zintegrowane z najważniejszymi szlakami metabolicznymi roślin. Zaobserwowano bezpośrednią zależność pomiędzy intensywnością fotooddychania a odpornością na rozmaite stresy abiotyczne. Uważa się też, że może ono być rodzajem „zaworu bezpieczeństwa" pozwalającego zużywać NADPH w sytuacji, gdy powstaje on w nadmiarze. Nadtlenek wodoru, który jest wytwarzany w czasie fotooddychania może pełnić funkcję ochronną podczas ataku patogenu. Postulowano również, że fotooddychanie może także uczestniczyć w syntezie seryny [1].

Mutanty enzymów uczestniczących w fotooddychaniu wykazują upośledzony wzrost $\mathrm{w}$ normalnej atmosferze [50]. Wyciszanie genów kodujących te enzymy również prowadziło do obniżenia produktywności roślin transgenicznych [1].

Zastosowano zatem inną strategię - selekcjonowano rośliny, które tolerowały podwyższone stężenie tlenu. Większość takich roślin cechowała się podwyższonym poziomem katalazy. Nie znaleziono natomiast żadnej, u której tolerancja na wysokie stężenia tlenu wynikałaby z ograniczonego fotooddychania [51]. Obserwowano pozytywną korelację pomiędzy produktywnością a natężeniem fotooddychania, wynikającą z tego, że rośliny o wysokiej produktywności cechuje wyższa intensywność fotosyntezy [52]. Co ciekawe, nadekspresja genów kodujących wybrane enzymy uczestniczące $\mathrm{w}$ fototoddychaniu u Arabidopsis thaliana i ryżu prowadziła do zwiększenia wydajności fotosyntezy i szybkości wzrostu [1]. Postulowano, że intermediaty fotooddychania uczestniczą w regulacji fotosyntezy [53].

Skoro obniżenie intensywności fotooddychania nie prowadziło do podwyższenia produktywności roślin, zaproponowano inne rozwiązania. Polegały one na wprowadzeniu alternatywnych, mniej wymagających energetycznie szlaków metabolizmu fosfoglikolanu.

Grupa Maiera [54], wprowadziła do chloroplastów A. thaliana szlak katabolizmu 2-fosfoglikolanu, prowadzący do przekształcenia go do dwóch cząsteczek $\mathrm{CO}_{2}$. Wprawdzie w jego wyniku obydwa atomy węgla wchodzące w skład fosfoglikolanu zostają całkowicie utlenione (a nie jeden, jak to ma miejsce $\mathrm{w}$ natywnym cyklu), ale nie dochodzi do zużywania ATP oraz strat $\mathrm{NH}_{3}$. Ponadto, $\mathrm{w}$ transgenicznych roślinach uzyskanych przez Maiera i wsp. $\mathrm{CO}_{2}$ pochodzący $\mathrm{z}$ rozkładu fosfoglikolanu jest uwalniany $\mathrm{w}$ chloroplastach, dzięki czemu może być ponownie asymilowany. Kebeish i współpracownicy [55] wprowadzili do A. thaliana szlak katabolizmu 2-fosfoglikolanu występujący u E. coli. Glikolan jest $\mathrm{w}$ nim przekształcany do glicerynianu, co pozwala ominąć reakcje zachodzące w mitochondriach i peroksysomach. Dzięki temu, zużywane jest mniej ATP i siły redukcyjnej. Transgeniczne rośliny, uzyskane przez obie wyżej wymienione grupy, wykazywały zwiększoną produkcję biomasy, jednak tylko w warunkach dnia krótkiego i przy optymalnym zaopatrzeniu w wodę i azot $[54,55]$. Przeprowadzono także eksperyment, mający na celu ekspresję genów kodujących karboligazę glioksalanu i izomerazę hydroksypirogronianu z E. coli w tytoniu. Miało to umożliwić pominięcie mitochondrialnego etapu fotooddychania, gdzie dochodzi do utraty $\mathrm{CO}_{2} \mathrm{i} \mathrm{NH}_{3}$. Niestety, uzyskane rośliny transgeniczne nie produkowały izomerazy hydroksypirogronianu [56]. Rozwiązanie zaproponowane przez grupę Kebeisha zostało wykorzystane przez innych badaczy. Otrzymano transgeniczny lnicznik siewny (roślina oleista), który cechował się podwyższoną produkcją nasion [57]. Transgeniczny ziemniak z ekspresją jednego z enzymów wykorzystanych przez Kebeisha i współautorów, dehydrogenazy glikolanu, pozwalał na uzyskanie podwyższonego plonu z bulw [58].

Znane są jeszcze dwa inne szlaki metabolizowania fosfoglikolanu [1]. Próby wprowadzenia enzymów jednego z tych szlaków, występującego naturalnie u sinic, nie doprowadziły jednak do uzyskania roślin A. thaliana o podwyższonej produktywności [10].

Badano także $A$. thaliana i tytoń z nadekspresją genu kodującego syntetazę glutaminy. Spodziewano się, że pozwoli to na wydajniejsze wiązanie $\mathrm{NH}_{3}$ uwalnianego podczas fotooddychania. Uzyskane rośliny transgeniczne rosły szybciej od kontrolnych $\mathrm{w}$ warunkach sprzyjających fotoodychaniu [1].

U zielonych bakterii nitkowatych, glioksalan jest pierwotnym produktem asymilacji $\mathrm{HCO}_{3}{ }^{-}$, odbywającej się za 
pomocą tzw. dicyklu 3-hydroksypropionowego [9]. Shih i współaut. [2014] wprowadzili do sinicy Synechococcus elongatus geny kodujące enzymy cyklu 3-hydroksypropionowego, pozwalające przekształcać glikolan do pirogronianu. Wykazano, że wprowadzony fragment szlaku był aktywny $\mathrm{w}$ transgenicznych sinicach, jednak nie rosły one szybciej w porównaniu z kontrolą [59].

\section{POZOSTAŁE KONCEPCJE}

Zaproponowano także inne sposoby podniesienia wydajności fotosyntezy wykorzystując zdobycze inżynierii genetycznej. Eksperymenty z wykorzystaniem roślin z obniżoną ekspresją genów kodujących enzymy cyklu Calvina wykazały, że na szybkość przepływu metabolitów przez ten cykl wpływają również enzymy uczestniczące $\mathrm{w}$ fazie regeneracji. Spośród tych enzymów najistotniejszą rolę pełni fosfataza sedoheptulozo-1,7-bisfosforanu. Nawet niewielkie zmniejszenie ilości tego białka powadziło do obniżenia wydajności fotosyntezy i spowolnienia wzrostu [60]. Transgeniczny tytoń z nadekspresją genu kodującego fosfatazę sedoheptulozo-1,7-bisfosforanu pochodzącego z A. thaliana lub z sinic asymilował $\mathrm{CO}_{2}$ wydajniej niż typ dziki $[61,62]$.

Postulowano także całkowite zastąpienie cyklu Calvina innym szlakiem pozwalającym na asymilację węgla. Obecnie znanych jest sześć szlaków wiązania $\mathrm{CO}_{2}$, z czego trzy są wrażliwe na tlen [9]. Spośród pozostałych największe zainteresowanie wzbudza wspomniany wyżej dicykl 3-hydroksypropionianowy. Uzyskano transgeniczną E. coli z ekspresją genów kodujących wybrane enzymy tego cyklu [63].

\section{PROBLEMY I PERSPEKTYWY}

Próby zwiększenia wydajności fotosyntezy z wykorzystaniem inżynierii genetycznej napotykają liczne przeszkody. Fotosynteza, jako jeden z najważniejszych procesów metabolicznych, jest ściśle powiązana z innymi podstawowymi szlakami. Zmiana pojedynczego etapu/elementu prowadzi do zaburzenia interakcji z resztą metabolizmu. $\mathrm{Z}$ tego względu konieczne są dalsze badania podstawowe, pozwalające lepiej zrozumieć powiązania pomiędzy poszczególnymi szlakami metabolicznymi, zarówno na poziomie wymiany intermediatów, jak i wzajemnej regulacji aktywności enzymów przez produkty różnych szlaków oraz udział tych ostatnich w regulacji ekspresji genów [3].

Ograniczenia wynikają także z dostępnych metod. Inżynieria fotosyntezy na większą skalę wymaga skutecznej transformacji genomu chloroplastowego i jądrowego jednocześnie. Konieczne jest również wprowadzanie dużych fragmentów DNA, kodujących całe zestawy białek. Dla wielu gatunków roślin trudno jest uzyskać stabilną transformację, czy wydajną ekspresję wprowadzonego transgenu. Również i w tym przypadku konieczne są intensywne badania podstawowe dotyczące promotorów, terminatorów transkrypcji oraz sekwencji sygnałowych. Choć należy zaznaczyć, że metodologia związana z inżynierią genetyczną cały czas się rozwija i np. dla Nicotiana sylvestris opracowano skuteczne techniki transformacji genomu plastydowego i jądrowego [3].
Ostatnie lata przyniosły też bardzo obiecujące metody pozwalające na wprowadzanie precyzyjnych zmian sekwencji DNA, przede wszystkim tzw. system CRISPR/Cas9, wykorzystujący zmodyfikowaną bakteryjną nukleazę współpracującą z białkiem wiążącym RNA. Cząsteczka RNA służy za wzór pozwalający na odnajdywanie, a następnie cięcie komplementarnych fragmentów DNA [64]. Kolejnym ważnym osiągnięciem jest konstrukcja sztucznych minichromosomów, za pomocą których można wprowadzać do roślin większą liczbę genów [65]. Można zatem mieć nadzieję, że w przyszłości modyfikacja fotosyntezy pozwalająca na podniesienie jej wydajności u roślin uprawnych będzie możliwa w znacznie większym stopniu niż obecnie.

\section{PIŚMIENNICTWO}

1. Betti M, Bauwe H, Busch FA, Fernie AR, Keech O, Levey M, Ort DR, Parry MA, Sage R, Timm S, Walker B (2016) Manipulating photorespiration to increase plant productivity: recent advances and perspectives for crop improvement. J Exp Bot 67: 2977-2988

2. Long SP, Zhu XG., Naidu SL, Ort DR (2006) Can improvement in photosynthesis increase crop yields? Plant Cell Environ 29: 315-330

3. Ort DR, Merchant SS, Alric J, Barkan A, Blankenship RE, Bock R, Croce R, Hanson MR, Hibberd JM, Long SP, Moore TA (2015) Redesigning photosynthesis to sustainably meet global food and bioenergy demand. Proc Natl Acad Sci 112: 8529-8536

4. Hitchcock A, Jackson PJ, Chidgey JW, Dickman MJ, Hunter CN, Canniffe DP (2016) Biosynthesis of chlorophyll $a$ in a purple bacterial phototroph and assembly into a plant chlorophyll-protein complex. ACS Synth Biol 5: 948-954

5. Drewry DT, Kumar P, Long SP (2014) Simultaneous improvement in productivity, water use, and albedo through crop structural modification. Global Change Biol 20: 1955-1967

6. Beckmann J, Lehr F, Finazzi G, Hankamer B, Posten C, Wobbe L, Kruse $\mathrm{O}$ (2009) Improvement of light to biomass conversion by de-regulation of light-harvesting protein translation in Chlamydomonas reinhardtii. J Biotechnol 142: 70-77

7. Kirst H, Formighieri C, Melis A (2014) Maximizing photosynthetic efficiency and culture productivity in cyanobacteria upon minimizing the phycobilisome light-harvesting antenna size. Biochim Biophys Acta: Bioenerg 1837: 1653-1664

8. Mussgnug JH, Thomas-Hall S, Rupprecht J, Foo A, Klassen V, McDowall A, Schenk, PM, Kruse O, Hankamer B (2007) Engineering photosynthetic light capture: impacts on improved solar energy to biomass conversion. Plant Biotechnol J 5: 802-814

9. Hügler M, Sievert SM (2011) Beyond the Calvin cycle: autotrophic carbon fixation in the ocean. Mar Sci 3: 261-289

10. Hagemann M, Bauwe H (2016) Photorespiration and the potential to improve photosynthesis. Curr Op Chem Biol 35: 109-116

11. Hagemann M, Kern R, Maurino VG, Hanson DT, Weber AP, Sage RF, Bauwe H (2016) Evolution of photorespiration from cyanobacteria to land plants, considering protein phylogenies and acquisition of carbon concentrating mechanisms. J Exp Bot 67: 2963-2976

12. Bauwe H, Hagemann M, Fernie AR (2010) Photorespiration: players, partners and origin. Trends Plant Sci 15: 330-336

13. Peterhansel C, Krause K, Braun HP, Espie GS, Fernie AR, Hanson DT, Keech O, Maurino VG, Mielewczik M, Sage RF (2013) Engineering photorespiration: current state and future possibilities. Plant Biol 15: 754-758

14. Erb TJ, Zarzycki J (2016) Biochemical and synthetic biology approaches to improve photosynthetic $\mathrm{CO}_{2}$-fixation. Curr Op Chem Biol 34: $72-79$

15. Whitney SM, Houtz RL, Alonso H (2011) Advancing our understanding and capacity to engineer nature's $\mathrm{CO}_{2}$-sequestering enzyme, $\mathrm{Ru}$ bisco. Plant Physiol 155: 27-35 
16. Suzuki Y, Miyamoto T, Yoshizawa R, Mae T, Makino A (2009) Rubisco content and photosynthesis of leaves at different positions in transgenic rice with an overexpression of RBCS. Plant Cell Environ 32: 417-427

17. Parry MA, Andralojc PJ, Mitchell RA, Madgwick PJ, Keys AJ (2003) Manipulation of Rubisco: the amount, activity, function and regulation. J Exp Bot 54: 1321-1333

18. Tcherkez GG, Farquhar GD, Andrews TJ (2006) Despite slow catalysis and confused substrate specificity, all ribulose bisphosphate carboxylases may be nearly perfectly optimized. Proc Natl Acad Sci USA 103: 7246-7251

19. Parry MA, Andralojc PJ, Scales JC, Salvucci ME, Carmo-Silva AE, Alonso H, Whitney SM (2013) Rubisco activity and regulation as targets for crop improvement. J of Exp Bot 64: 717-730

20. Young JN, Heureux AM, Sharwood RE, Rickaby RE, Morel FM, Whitney SM (2016) Large variation in the Rubisco kinetics of diatoms reveals diversity among their carbon-concentrating mechanisms. J Exp Bot 67: 3445-3456

21. Mueller-Cajar O, Whitney SM (2008) Directing the evolution of Rubisco and Rubisco activase: first impressions of a new tool for photosynthesis research. Photosynth Res 98: 667-675

22. Parikh MR, Greene DN, Woods KK, Matsumura I (2006) Directed evolution of RuBisCO hypermorphs through genetic selection in engineered E. coli. Prot Eng Des Sel 19: 113-119

23. Tabita FR, Satagopan S, Hanson TE, Kreel NE, Scott SS (2008) Distinct form I, II, III, and IV Rubisco proteins from the three kingdoms of life provide clues about Rubisco evolution and structure/function relationships. J Exp Bot 59: 1515-1524

24. Carmo-Silva E, Scales JC, Madgwick PJ, Parry MA (2015) Optimizing Rubisco and its regulation for greater resource use efficiency. Plant Cell Environ 38: 1817-1832

25. Sharwood RE, von Caemmerer S, Maliga P, Whitney SM (2008) The catalytic properties of hybrid Rubisco comprising tobacco small and sunflower large subunits mirror the kinetically equivalent source $\mathrm{Ru}-$ biscos and can support tobacco growth. Plant Physiol 146: 83-96

26. Wang YL, Zhou JH, Wang YF, Bao JS, Chen HB (2001) Properties of hybrid enzymes between Synechococcus large subunits and higher plant small subunits of ribulose-1, 5-bisphosphate carboxylase/oxygenase in Escherichia coli. Arch Biochem Biophys 396: 35-42

27. Kurek I, Chang TK, Bertain SM, Madrigal A, Liu L, Lassner MW, Zhu G (2007) Enhanced thermostability of Arabidopsis Rubisco activase improves photosynthesis and growth rates under moderate heat stress. Plant Cell 19: 3230-3241

28. Badger MR, Price GD (2003) $\mathrm{CO}_{2}$ concentrating mechanisms in cyanobacteria: molecular components, their diversity and evolution. J Exp Bot 54: 609-622

29. Singh SK, Sundaram S, Sinha S, Rahman MA, Kapur S (2016) Recent advances in $\mathrm{CO}_{2}$ uptake and fixation mechanism of cyanobacteria and microalgae. Crit Rev Environ Sci Technol 46: 1297-1323

30. Price GD, Badger MR, Woodger FJ, Long BM (2008) Advances in understanding the cyanobacterial $\mathrm{CO}_{2}$-concentrating-mechanism $(\mathrm{CCM})$ : functional components, $\mathrm{C}_{\mathrm{i}}$ transporters, diversity, genetic regulation and prospects for engineering into plants. J Exp Bot 59: 1441-1461

31. Rae BD, Long BM, Whitehead LF, Förster B, Badger MR, Price GD (2013) Cyanobacterial carboxysomes: microcompartments that facilitate $\mathrm{CO}_{2}$ fixation. J Mol Microbiol Biotechnol 23: 300-307

32. Losh JL, Young JN, Morel FM (2013) Rubisco is a small fraction of total protein in marine phytoplankton. New Phytol 198: 52-58

33. Hanson MR, Lin MT, Carmo-Silva AE, Parry MA (2016) Towards engineering carboxysomes into C3 plants. Plant J 87: 38-50

34. Lin MT, Occhialini A, Andralojc PJ, Parry MA, Hanson MR (2014) A faster Rubisco with potential to increase photosynthesis in crops. Nature 513: 547-550

35. Occhialini A, Lin MT, Andralojc PJ, Hanson MR, Parry MA (2016) Transgenic tobacco plants with improved cyanobacterial Rubisco expression but no extra assembly factors grow at near wild type rates if provided with elevated $\mathrm{CO}_{2}$. Plant J 85: 148-160
36. Lin MT, Occhialini A, Andralojc PJ, Devonshire J, Hines KM, Parry MA, Hanson MR (2014) $\beta$-Carboxysomal proteins assemble into highly organized structures in Nicotiana chloroplasts. Plant J 79: 1-12

37. Pengelly JJL, Förster B, von Caemmerer S, Badger MR, Price GD, Whitney SM, (2014) Transplastomic integration of a cyanobacterial bicarbonate transporter into tobacco chloroplasts. J Exp Bot 65: 3071-3080

38. Rolland V, Badger MR, Price GD (2016) Redirecting the cyanobacterial bicarbonate transporters BicA and SbtA to the chloroplast envelope: soluble and membrane cargos need different chloroplast targeting signals in plants. Front Plant Science 7: 185

39. Uehara S, Adachi F, Ito-Inaba Y, Inaba T (2016) Specific and efficient targeting of cyanobacterial bicarbonate transporters to the inner envelope membrane of chloroplasts in Arabidopsis. Front Plant Sci 7: 16

40. Atkinson N, Feike D, Mackinder L, Meyer MT, Griffiths H, Jonikas MC, Smith AM, McCormick AJ (2015) Introducing an algal carbon-concentrating mechanism into higher plants: location and incorporation of key components. Plant Biotechnol J 14: 1302-1315

41. Gowik U, Westhoff $\mathrm{P}$ (2011) The path from $\mathrm{C}_{3}$ to $\mathrm{C}_{4}$ photosynthesis. Plant Physiol 155: 56-63

42. Sage RF, Christin PA, Edwards EJ (2011) The $C_{4}$ plant lineages of planet Earth. J Exp Bot 62: 3155-3169

43. Covshoff S, Hibberd JM (2012) Integrating $C_{4}$ photosynthesis into $C_{3}$ crops to increase yield potential. Curr Op Biotechnol 23: 209-214

44. Miyao M, Masumoto C, Miyazawa SI, Fukayama H (2011) Lessons from engineering a single-cell $\mathrm{C}_{4}$ photosynthetic pathway into rice. J Exp Bot 62: 3021-3029

45. Raines CA (2006) Transgenic approaches to manipulate the environmental responses of the $\mathrm{C}_{3}$ carbon fixation cycle. Plant Cell Environ 29: 331-339

46. von Caemmerer S, Quick WP, Furbank RT (2012) The development of $\mathrm{C}_{4}$ rice: current progress and future challenges. Sci 336: 1671-1672

47. Kajala K, Covshoff S, Karki S, Woodfield H, Tolley BJ, Dionora MJA, Mogul RT, Mabilangan AE, Danila FR, Hibberd JM, Quick WP (2011) Strategies for engineering a two-celled $\mathrm{C}_{4}$ photosynthetic pathway into rice. J Exp Bot 62: 3001-3010

48. Sharpe RM, Offermann S (2014) One decade after the discovery of single-cell $\mathrm{C}_{4}$ species in terrestrial plants: what did we learn about the minimal requirements of $\mathrm{C}_{4}$ photosynthesis? Photosynth Res 119: 169180

49. Häusler RE, Hirsch HJ, Kreuzaler F, Peterhänsel C (2002) Overexpression of $\mathrm{C}_{4}$-cycle enzymes in transgenic $\mathrm{C}_{3}$ plants: a biotechnological approach to improve $\mathrm{C}_{3}$-photosynthesis. J Exp Bot 53: 591-607

50. Timm S, Bauwe H (2013) The variety of photorespiratory phenotypes - employing the current status for future research directions on photorespiration. Plant Biol 15: 737-747

51. Zelitch I (1989) Selection and characterization of tobacco plants with novel $\mathrm{O}_{2}$-resistant photosynthesis. Plant Physiol 90: 1457-1464

52. Aliyev JA (2012) Photosynthesis, photorespiration and productivity of wheat and soybean genotypes. Physiol Plant sx145: 369-383

53. Timm S, Florian A, Wittmiß M, Jahnke K, Hagemann M, Fernie AR, Bauwe H (2013) Serine acts as a metabolic signal for the transcriptional control of photorespiration-related genes in Arabidopsis. Plant Physiol 162: 379-389

54. Maier A, Fahnenstich H, von Caemmerer S, Engqvist MK, Weber AP, Flügge UI, Maurino VG (2012) Transgenic introduction of a glycolate oxidative cycle into $A$. thaliana chloroplasts leads to growth improvement. Front Plant Sci 3: 38

55. Kebeish R, Niessen M, Thiruveedhi K, Bari R, Hirsch HJ, Rosenkranz R, Stäbler N, Schönfeld B, Kreuzaler F, Peterhänsel C (2007) Chloroplastic photorespiratory bypass increases photosynthesis and biomass production in Arabidopsis thaliana. Nature Biotechnol 25: 593-599

56. de Carvalho J, Madgwick PJ, Powers SJ, Keys AJ, Lea PJ, Parry MA (2011) An engineered pathway for glyoxylate metabolism in tobacco plants aimed to avoid the release of ammonia in photorespiration. BMC Biotechnol 11: 1

57. Dalal J, Lopez H, Vasani NB, Hu Z, Swift JE, Yalamanchili R, Dvora M, Lin X, Xie D, Qu R, Sederoff HW (2015) A photorespiratory bypass 
increases plant growth and seed yield in biofuel crop Camelina sativa. Biotechnol Biofuels 8: 1

58. Nölke G, Houdelet M, Kreuzaler F, Peterhänsel C, Schillberg S (2014) The expression of a recombinant glycolate dehydrogenase polyprotein in potato (Solanum tuberosum) plastids strongly enhances photosynthesis and tuber yield. Plant Biotechnol J 12: 734-742

59. Shih PM, Zarzycki J, Niyogi KK, Kerfeld CA (2014) Introduction of a synthetic $\mathrm{CO}_{2}$-fixing photorespiratory bypass into a cyanobacterium. J Biol Chem 289: 9493-9500

60. Raines CA (2011) Increasing photosynthetic carbon assimilation in $\mathrm{C}_{3}$ plants to improve crop yield: current and future strategies. Plant Physiol 155: 36-42

61. Lefebvre S, Lawson T, Fryer M, Zakhleniuk OV, Lloyd JC, Raines CA (2005) Increased sedoheptulose-1,7-bisphosphatase activity in transgenic tobacco plants stimulates photosynthesis and growth from an early stage in development. Plant Physiol 138: 451-460
62. Miyagawa Y, Tamoi M, Shigeoka S (2001) Overexpression of a cyanobacterial fructose-1,6-/sedoheptulose-1,7-bisphosphatase in tobacco enhances photosynthesis and growth. Nature Biotechnol 19: 965-969

63. d Mattozzi M, Ziesack M, Voges MJ, Silver PA, Way JC (2013) Expression of the sub-pathways of the Chloroflexus aurantiacus 3-hydroxypropionate carbon fixation bicycle in E. coli: Toward horizontal transfer of autotrophic growth. Metabol Eng 16: 130-139

64. Cong L, Ran FA, Cox D, Lin S, Barretto R, Habib N, Hsu PD, Wu X, Jiang W, Marraffini LA, Zhang F (2013) Multiplex genome engineering using CRISPR/Cas systems. Science 339: 819-823

65. Carlson SR, Rudgers GW, Zieler H, Mach JM, Luo S, Grunden E, Krol C, Copenhaver G.P, Preuss D (2007) Meiotic transmission of an in vitro-assembled autonomous maize minichromosome. PLoS Genet 3: e179

\title{
Genetic engineering as a method for the improvement of photosynthesis
}

\section{Beatrycze Nowicka, Jerzy Kruk}

Department of Plant Physiology and Biochemistry, Faculty of Biochemistry, Biophysics and Biotechnology, Jagiellonian University, 7 Gronostajowa St., 30-387 Kraków, Poland

凶e-mail: jerzy.kruk@uj.edu.pl

Key words: $\mathrm{C}_{4}$ plants, $\mathrm{CO}_{2}$ assimilation, photorespiration, genetic engineering, carbon concentrating mechanisms, Rubisco

\begin{abstract}
The significant increase in crop productivity occurred in the second half $\mathrm{o}$ the $20^{\text {th }}$ century. However, it is thought that nowadays yield of main crop species reached its maximum. As we expect that the demand for plant products is going to increase during next century, it is necessary to develop new methods for yield improvement, other than traditional breeding. The redesign of photosynthesis using genetic engineering is one of the approaches postulated. The present article covers the main directions of research aimed to increase photosynthetic efficiency. The research covered by this review are: improvement of light capture, improvement of Rubisco and the regeneration phase of Calvin cycle, introducing carbon concentrating mechanisms to main crop species and reducing loss caused by photorespiration.
\end{abstract}

